\title{
Entrepreneurship and economic development: theory, evidence and policy
}

Citation for published version (APA):

Naudé, W. (2012). Entrepreneurship and economic development: theory, evidence and policy. UNUMERIT, Maastricht Economic and Social Research and Training Centre on Innovation and Technology. UNU-MERIT Working Papers No. 027

Document status and date:

Published: 01/01/2012

Document Version:

Publisher's PDF, also known as Version of record

\section{Please check the document version of this publication:}

- A submitted manuscript is the version of the article upon submission and before peer-review. There can be important differences between the submitted version and the official published version of record.

People interested in the research are advised to contact the author for the final version of the publication, or visit the DOI to the publisher's website.

- The final author version and the galley proof are versions of the publication after peer review.

- The final published version features the final layout of the paper including the volume, issue and page numbers.

Link to publication

\footnotetext{
General rights rights.

- You may freely distribute the URL identifying the publication in the public portal. please follow below link for the End User Agreement:

www.umlib.nl/taverne-license

Take down policy

If you believe that this document breaches copyright please contact us at:

repository@maastrichtuniversity.nl

providing details and we will investigate your claim.
}

Copyright and moral rights for the publications made accessible in the public portal are retained by the authors and/or other copyright owners and it is a condition of accessing publications that users recognise and abide by the legal requirements associated with these

- Users may download and print one copy of any publication from the public portal for the purpose of private study or research.

- You may not further distribute the material or use it for any profit-making activity or commercial gain

If the publication is distributed under the terms of Article $25 \mathrm{fa}$ of the Dutch Copyright Act, indicated by the "Taverne" license above, 


\section{I UNITED NATIONS \\ UNIVERSITY \\ UNU-MERIT}

\section{Working Paper Series}

\section{\#2012-027}

Entrepreneurship and economic development: Theory, evidence and policy Wim Naudé

Maastricht Economic and social Research institute on Innovation and Technology (UNU-MERIT) email: info@merit.unu.edu | website: http://www.merit.unu.edu

Maastricht Graduate School of Governance (MGSoG)

email: info-governance@maastrichtuniversity.nl | website: http://mgsog.merit.unu.edu

Keizer Karelplein 19, 6211 TC Maastricht, The Netherlands

Tel: (31) (43) 388 4400, Fax: (31) (43) 3884499 
UNU-MERIT Working Papers

ISSN 1871-9872

Maastricht Economic and social Research Institute on Innovation and Technology, UNU-MERIT

Maastricht Graduate School of Governance

MGSoG

UNU-MERIT Working Papers intend to disseminate preliminary results of research carried out at UNU-MERIT and MGSoG to stimulate discussion on the issues raised. 


\title{
Entrepreneurship and Economic Development: \\ Theory, Evidence and Policy
}

Wim Naudé ${ }^{1}$

\begin{abstract}
This paper provides an overview of the state of the art of the intersection of development and entrepreneurship. Given the neglect of entrepreneurship by development scholars it deals with (i) recent theoretical insights from the intersection of entrepreneurship and development studies; (ii) the empirical evidence on that relationship between entrepreneurship and development; and (iii) fresh insights for entrepreneurship policy for development that emerges from recent advanced in this area, including female entrepreneurship in developing countries.
\end{abstract}

Key words: Entrepreneurship, development, small business, private sector development

JEL Classification numbers: M13, O10, O17, O40

10 April 2012

1 Professorial Fellow, UNU-MERIT and Maastricht Graduate School of Governance, University of Maastricht and Maastricht School of Management, The Netherlands, email: w.naude@maastrichtuniversity.nl or naude@msm.nl 


\section{Introduction}

Adam Smith, founding father of modern economics ‘detested business men’ (Lewis, 1988: 35). Development scholars and development economists in particular have, if not detesting business men or entrepreneurs, (benignly) neglected them. Following Leff (1979:51) many development scholars took the position that 'entrepreneurship is no longer a problem' or a 'relevant constraint on the pace of development' in developing countries. Entrepreneurship scholars on other hand have been more concerned with the who, why and how of entrepreneurship rather than with the impact of entrepreneurship on development or developing countries (Shane, 1997; Bruton et al. 2008); a situation described as a 'scholarly disconnect' (Audretsch et al., 2007: 1-2).

Why does this matter? First, it is widely believed that entrepreneurship is beneficial for economic growth and development (Audretsch et al., 2006). Second, entrepreneurship has been remarkably resurgent over the past three decades in countries that achieved substantial poverty reduction - e.g. in China (Mohapatra et al., 2007). Third, donors and international development agencies have been turning to entrepreneurship to improve the effectiveness and sustainability of aid (Pronk, 2003; Hubbard and Duggan, 2009).

However, the theoretical and empirical cases for understanding the role of entrepreneurship are not yet solid. Evidence on whether entrepreneurship matters for economic growth is not straightforward; how entrepreneurship has been promoted and how it contributed to development in countries like China and the East Asian Tigers is still a matter of contention; and whether and why private sector development initiatives may be effective is not well understood (Bruhn and Zia, 2011; Karlan and Valdivia; 2010; Oosterbeek et al. 2010; Klinger and Schündeln; 2010).

Closer scrutiny of the relationship between entrepreneurship and economic development is therefore needed. In order to stimulate the development-entrepreneurship discourse it may be necessary to first attempt to formalize or reconcile the role of entrepreneurship in the "grand ideas" of development economics, and to consider how this resonates with available evidence, and what this means for policy (Naudé, 2010).

There are at least three "grand" ideas in development economics. The first is that development requires a structural transformation of what, how and where production and consumption takes place: from low-value added, low productivity and mainly rural (and agricultural) based activities to more productive, higher value added activities in services and manufacturing located largely in cities. The second idea is that development is a multi-dimensional concept that requires more than just the eradication of income poverty. The third is the idea that market failures are prevalent and that the state has an important coordinating and regulatory role to play in development. 
All of these grand ideas are currently at the forefront of thought in development, and much of what development scholars are occupying themselves with either directly or indirectly resort under the umbrellas of these ideas.

Accordingly this paper provides an overview of the state of the art in terms of development and entrepreneurship. It is concerned with the theoretical insights from the intersection of entrepreneurship and development studies (section 2); with the empirical evidence on that relationship between entrepreneurship and development (section 3); and on the fresh insights for entrepreneurship policy for development that emerges from recent advanced in this area (section 4).

\section{Theoretical Perspectives on Entrepreneurship in Development}

\subsection{Concept, Definitions and Relevance for Development}

Entrepreneurship definitions can be categorized into behavioral and occupational definitions (Naudé, 2010). Recently Gries and Naudé (2011) proposed a synthesis definition.

- Behavioural definitions

Schumpeter (1950; 1961) famously defined the entrepreneur as the coordinator of production and agent of change ('creative destruction'). As such the entrepreneur is an innovator, rather than a manager or financier. Scholars who share this view of entrepreneurship do not consider entrepreneurship to be very important in earlier stages of economic development - they seen the contribution of entrepreneurship to be much more important at later stages of development, where economic growth is driven by knowledge and competition that pushes out the production possibility frontier. At earlier stages of development growth is not as such driven by entrepreneurship but by factor accumulation (Porter et al. 2002; Ács and Naudé, 2012).

Other behavioural definitions allow for a more substantial role for entrepreneurship in developing countries. Kirzner (1973) and Schultz's (1975) views of the entrepreneur as someone who facilitates adjustment to change by spotting opportunities for profitable arbitrage (and 'disequilibrium' situations in the market) has found resonance amongst scholars who emphasize the opportunity-grabbing-for-profit nature of entrepreneurship (e.g. Shane and Ventakaram, 2000) and who considers market disequilibria to be common in developing country circumstances.

Behavioural definitions also include definitions that stress the risk-taking dimension of entrepreneurship. Kanbur (1979:773) described the entrepreneur as one who 'manages the production function' by paying workers wages (which are more certain than profits) and shouldering the risks and uncertainties of production. Such definitions are seen as very relevant for developing country contexts characterized by high risk and uncertainty. The predominance of small firms in developing countries - the bulk of entrepreneurship studies in developing 
countries are concerned with small and medium enterprises (SMEs) (Ayyagari et al. 2011) - has been postulated to be a symptom of economy-wide uncertainty, where the probability of success is small (Wiggens, 1995).

From these views policy implications follow - for instance that government policy for promoting entrepreneurship should reduce uncertainty / transaction costs. Policy though, is only a proximate cause for risk and uncertainty and in recent years development scholars have recognized 'institutions' (the "rules of the game") as the ultimate determinant of development. Institutions affect not only the supply but perhaps even more importantly the allocation of entrepreneurship. According to Baumol (1990:895) entrepreneurial ability can be allocated towards productive, unproductive, or even destructive activities. He defines entrepreneurs as 'persons who are ingenious and creative in finding ways that add to their own wealth, power, and prestige' (Ibid, 1990:987). Underdevelopment may not due to an insufficient supply of entrepreneurs, but due to institutional weaknesses that result in a 'lack of profit opportunities tied to activities that yield economic growth’ (Coyne and Leeson, 2004:236).

\section{- Occupational definitions}

In economic theory entrepreneurship has been modeled as an occupational choice between selfemployment and wage-employment (see Lucas, 1978; Evans and Jovanovic, 1989; and Murphy et al., 1991). Hence someone will become an entrepreneur if profits and the non-pecuniary benefits from self-employment exceed wage income plus additional benefits from being in wage employment. Entrepreneurship is thus often synonymous with self-employment. Because selfemployment is often not by choice but by necessity, a distinction if often made in between necessity and opportunity entrepreneurs - as in for instance the Global Entrepreneurship Monitor (GEM - see Reynolds et al., 2005).

- A synthesis definition

Gries and Naudé (2011) proposed a synthesis definition; it combines behavioural and occupational views and relates entrepreneurship to the three big ideas in development economics as discussed in the introduction. They define entrepreneurship as "the resource, process and state of being through and in which individuals utilize positive opportunities in the market by creating and growing new business firms”. As a resource, entrepreneurship has the instrumental value that it is accorded in economics; as process it accords to the attention given in management studies on the start-up, growth and exit of firms and as state-of-being it recognizes that entrepreneurship is not limited to being instrumental, it is often valued in itself (as will be explained in greater detail in section 3).

Gries and Naudé (2011) emphasize the process value of entrepreneurship and describe entrepreneurial opportunities in a broader sense than is usual in the entrepreneurship literature. For instance Shane and Venkataraman (2000) define an 'opportunity' as when goods can be sold at a profit. From a development perspective this is inadequate because it implies that utility from 
entrepreneurship depends only on monetary gains. "Opportunities" should include situations when persons can create new firms that will further the kind of lives they desire.

Their use of the adjective "positive" in relation to opportunities reflects a subjective assessment that while entrepreneurial ability may be allocated to destructive activities (as in Baumol, 1990) it should not be defined as entrepreneurship if it detracts from either individual or societal welfare.

The following sub-sections will consider the contribution that entrepreneurship can make to illuminate the three "big ideas" in development economics.

\subsection{Structural economic transformation and entrepreneurship}

One of the seminal contributions to development economics has been dual economy models inspired by Lewis (1954) and utilized to explain the structural transformation of underdeveloped economies.

Gries and Naudé (2010) extended the Lewis model to explicitly incorporate the entrepreneur. They follow the Lewis-model distinction between a traditional and modern sector, and underpin this with micro-foundations (optimizing households, firms and labour market matching). They also distinguish between mature and start-up entrepreneurs, between large firms and small firms and between necessity and opportunity-driven entrepreneurship. In their model the transformation from a low-income, traditional economy to a modern economy involves significant changes to production methods, a process of change where entrepreneurs provide essential roles, including providing innovative intermediate inputs, permitting specialization and raising productivity and employment.

Their model builds on extends earlier work of Rada (2007), Peretto (1999) and Murphy et al (1991). In Rada (2007) entrepreneurs 'trigger' an investment in the modern sector once they have perceived profitable opportunities and facilitate the re-allocation of production factors from the traditional to the modern sector. Peretto (1999) provided a modified endogenous growth model that implied long-run structural transformation depends on the degree to which an economy can make a transition from a growth path driven by capital accumulation ('the Solow economy') to a growth path driven by knowledge accumulation (the 'innovation-driven' economy).

In structural change entrepreneurial ability has been accorded centre stage. Murphy et al (1991) provided a model that described firm size and the growth of the economy as a function of entrepreneurial ability. Nelson and Pack (1999) assigns a key role to the 'effectiveness of entrepreneurial ability' which they see as a vital determinant of the rate of assimilation of technology (1999:420) - as in Michelacci (2003) where entrepreneurial ability is vital for R\&D. In Nelson and Pack (1999) a 'rapid' expansion of skilled labour can only be absorbed if 
entrepreneurial ability is high, and that without entrepreneurial ability the returns to physical and human capital is low.

The process of structural change as facilitated by high ability entrepreneurs lead to firms adopting more complex production methods and producing more complex and specialized intermediate inputs. As a result the technological intensity of a country's economic structure increases (Ciccone and Matsuyama 1996). These structural changes have interesting implications for the development of entrepreneurship itself, so that entrepreneurship may be itself endogenous in the development process.

Ciccone and Matsuyama (1996) explains this in a model where they make a distinction between consumer goods and intermediate goods. If a particular economy produces a limited range of intermediate goods, they show that the final (consumer) goods sector will use 'primitive' production methods and will have little demand for sophisticated, new inputs. This will lead to lower incentives for potential entrepreneurs to start-up new firms. The economy can get stuck in such an underdevelopment trap with primitive production in its (small) modern sector. They also point out that there might, in such an 'underdevelopment trap' be a case for assistance to new start-ups since these can provide both pecuniary and technological externalities if they start producing new intermediate goods - which will induce final good producers to demand more of these (in turn improving the incentives for other entrepreneurs to start-up firms due to greater demand and the example provided in the application new technology). In this model, start-ups face positive start-up costs that include R\&D activities in bringing a new good to the market.

That entrepreneurs create a positive externality through bringing new goods to the market and in the process showcase new technology has been extended by Hausmann and Rodrik (2003) who point out that entrepreneurs provide not only these technological externalities in bringing new goods to market, but pecuniary externalities by providing information on the profitability of new activities. Entrepreneurs fulfill a 'cost-discovery' function in making sunk costs in a new activity which ex ante may or may not be profitable, but which will provide information ex post on such profitability to other entrepreneurs - information that often lacks in developing countries (Hausmann and Rodrik 2003).

Finally, an aspect of duality that is particularly pertinent to the debate on entrepreneurship in development is that between the formal and informal sector (Maloney 2004). De Paula and Scheinkman (2007) find that informal firms are often a form of 'evasive' entrepreneurship in order to evade taxes or regulations, or to engage in illegal trade. They also find that they are less efficient, less able to obtain finance, and more likely to be dominated by entrepreneurs of low ability. Thus the informal sector is much like the traditional/ subsistence sector in typical dual

economy models, and growth may be enhanced by encouraging entrepreneurs of high ability to 'migrate' to the formal sector.

\subsection{Multi-dimensional development and entrepreneurship}


The entrepreneurship literature generally takes a restricted view of development. Most empirical studies on the relationship between entrepreneurship and development have similarly been limited to GDP, productivity and employment growth as proxies for development - and not multi-dimensional development (Ács et al., 2008a, 2008b; van Praag and Versloot, 2007).

Gries and Naudé (2011) proposed a framework wherein entrepreneurship can contribute to multidimensional well-being by contributing towards not only what people are or has, but what they can achieve through their capabilities. This notion of human development -or human flourishing - has been pioneered by Sen (1990; 1995; 2000), Nussbaum (2000) and others and is known as the Capabilities Approach (CA).

Gries and Naudé (2011) argue that the CA can inform both theoretical thinking on and measurement of entrepreneurship. From a CA view entrepreneurship is a human functioning ${ }^{2}$ that can be valued as an end, and not just as a means to other ends. It can enrich human capabilities if people's complementary capabilities are expanded so that they can choose not to be entrepreneurs. An important implication from this approach is that the demand for entrepreneurs is not a derived demand as in the instrumentalist view (as e.g. in Casson et al., 2006).

Naudé, et al. (2012a;b) provide provisional empirical evidence supportive of the CA view of entrepreneurship proposed by Gries and Naudé (2011). Using individual level data from the Global Entrepreneurship Monitor (GEM) they find evidence of an inverse U-shape relationship between (opportunity) entrepreneurship and national happiness. This suggests opportunitymotivated entrepreneurship may contribute to a nation's happiness, but only up to a point. Not everybody should become entrepreneurs, and the happiness of a nation cannot be -indefinitely increased by increasing the numbers of (opportunity) entrepreneurs.

Although the literature on whether entrepreneurship matters for multidimensional development is scant, there has been more research on the subjective wellbeing (or or job satisfaction) of entrepreneurs (mostly measured as the self-employed). The evidence so far (more research is needed) suggests that entrepreneurs experience higher levels of job satisfaction than employees (Anderssen, 2008; Benz and Frey, 2008; Blanchflower, 2004; Lange, 2012; Parker and AjayiObe, 2003). They have also been found to be healthier, less prone to negative feelings and depression, and to experience flow, than employees (Bradley and Roberts, 2004; Ceja, 2009; Graham et al., 2004; Patzelt and Shepherd, 2011) and to experience, in line with the CA, 'procedural utility' (Block and Koellinger, 2009).

\subsection{Market failures, the state and entrepreneurship}

\footnotetext{
${ }^{2}$ The term functionings is central in the capabilities approach, and refers to 'valuable activities and states that make up people's well-being' (Alkire, 2005:1) and includes 'working, resting, being literate, being healthy, being part of a community, being respected’ (Robeyns, 2003:6).
} 
The third "grand idea" in development economics concerns market and state failures. In the aftermath of World War II, when development economics was founded the belief was that market failures were important to understand underdevelopment. During the 1980s however the government was seen as similarly subject to failure, and that such state failure could be worse than market failure. Hence, under a set of principles for market-oriented reform described as the 'Washington Consensus', many economists and international development agencies started to promote a reduction of the role of the state and the liberalization of markets. The implicit assumption was that the supply of entrepreneurship would be forthcoming once the constraints imposed by state interference were loosened. After the global financial crises of 2008 and 2009 wherein market liberalization and 'Washington Consensus' type policies were found to be complicit, the regulatory role of the state has been revived.

One role of the state that has received more attention is in industrial policy (Szirmai et al., 2012). Here, old models of import-protection and state-owned enterprises have made place for policies that rely more on the private sector and entrepreneurship, but with government still playing an important role to address market failures in the entrepreneurial start-up and growth process. For example some have argued that entrepreneurial entry may be sub-optimal due to the externalities generated by such entry - see e.g. the discussion of Hausmann and Rodrik (2003) in section 2.1 that may justify 'self-discovery' through supporting innovation by SMEs and new firm start-ups, e.g., by reducing regulations and requirements and/or providing subsidized credit.

In contrast to such support others have argued for taxing (regulating) entrepreneurship because it may cast negative externalities. De Meza and Webb (1987; 1999) make the case that credit market imperfections may lead to 'overinvestment' when banks cannot accurately judge entrepreneurial ability. Because banks cannot observe any entrepreneur's ability ex ante, interest rates on start-up capital will reflect average entrepreneurial ability. If the proportion of entrepreneurs of low ability increases, it will result in higher borrowing costs, which impose a negative externality on entrepreneurs of high ability, who will consequently borrow and invest less (Ghatak et al. 2007). The entry of entrepreneurs with low ability might also hinder development because such entrepreneurs may have less productive workers, who will earn reduced wages as a result, and in turn reduce the opportunity costs of self-employment, thereby causing the entry of even more low-ability entrepreneurs (Ghatak et al. 2007:2).

There is thus a clear case of the state to play a role in addressing the market failures that plague also entrepreneurial start-up and innovation activities; moreover this role will be different across different stages (Ács and Naudé, 2012) - although more research is clarify this, in particular given the fact that many countries exhibit various stages simultaneously in different sectors, and that countries can today leapfrog development.

Furthermore, the how of state support for entrepreneurship is essential - and this brings us to issues of entrepreneurship policy. For instance, private sector development (PSD) policies have tended to shy away from targeting entrepreneurs in specific sectors or industries for fear of 
distorting markets, and for fear of government failure - in particular the potential for such selective support to encourage rent-seeking and corruption. The design of entrepreneurship policies are therefore a delicate art, and one that is increasingly in need of rigorous evidence. In the next section I turn to what we can learn from the empirical evidence on the relationship between entrepreneurship and development.

\section{Empirical Evidence}

\subsection{Macro-level Relationship}

The three most important global/macro databases on entrepreneurial activity in countries all take a occupational/formal-firm view of entrepreneurship: the International Labour Organization (ILO) measures self-employment, the Global Entrepreneurship Monitor (GEM) measures startup rates of new firms, and the World Bank measures the registration of new firms. They are also concerned with formal as opposed to informal firms (for a discussion of these databases see Desai, 2010).

Studies using these databases have uncovered two sets of results. First, that there is a lack of clear empirical evidence of whether entrepreneurship drives economic growth (or productivity or employment) - studies find a mixed bag of results - and second, there seems to be an U-shaped relationship between entrepreneurship and a country's level of economic development (as measured by GDP per capita).

The U-shaped relationship implies a higher rate of entrepreneurial activity in low-income countries than in middle income countries (Carree et al., 2007; Wennekers et al., 2005). This result may reflect that entrepreneurs in developing countries are less innovative and tend to be proportionately more 'necessity' motivated (Ács et al., 2008a; Gollin, 2008). Higher levels of GDP may therefore be associated with more 'innovative' forms of entrepreneurship. Another implication is that rather than causality running from entrepreneurship to development, the causality may (also) run from development to entrepreneurship.

\subsection{Micro-Level Relationship}

Most micro-level studies of entrepreneurship has focused on the why and how of entrepreneurship, and not its impact on development. Nevertheless from a number of studies for instance on the productivity, innovativeness, growth and female entrepreneurs - much can be learned on whether and how entrepreneurship matter for development. One lesson is that the finding on the macro-level that it is innovative entrepreneurship (by implication entrepreneurial ability) that matter most for development seems to be supported by micro-level evidence.

Van Praag and Versloot (2007; 2008) consider the literature on the impact of entrepreneurship (according to various definitions) on employment, innovation and productivity growth. They find 
that (i) entrepreneurs do not spend more on R\&D than their counterparts, although the quality and efficiency of their innovation is higher; that (ii) their contribution to productivity growth is low; that (iii) the majority of entrepreneurs would earn higher incomes as wage employees, and (iv) that entrepreneurs create more jobs relative to non-entrepreneurs but that the quality of jobs they create is lower. Hence not all entrepreneurs drive development and not all entrepreneurs are innovative (Shane, 2009; Stam and Wennberg, 2009).

As these findings refer to the impact of the average entrepreneur it perhaps suggest that focusing on the average entrepreneur may not be the best policy stance - it may be better for and policy to focus on the small subset of entrepreneurs - innovative entrepreneurs - that do make a difference. Studies tend to find that innovative firms, particularly in high tech sectors, have on average higher levels of productivity, tend to do enjoy higher employment growth, and cause positive spillovers for other firms (Coad and Rao, 2008; Hall et al., 2009; Freel, 2000; Koski and Pajarinen, 2010; Rochina-Barrachina et al., 2010; Stam and Wennberg; 2009). A study from an emerging economy, Brazil, with the focus on a panel of manufacturing firms over the period 1996-2002 and that uses propensity score matching techniques finds that firms who engaged in technological innovation experienced a 10.8 to 12.5 percent higher growth in employment, a 18.1 to 21.7 percent higher growth in net revenue, a 10.8 to 11.9 percent higher growth in labour productivity and a 19.9 percent higher growth in market share (Kannebley et al., 2010).

Micro-level evidence on entrepreneurship and development has in recent years started to give attention to female entrepreneurs in developing countries - important given the key role of women in development and the still widespread discrimination against women. In an overview of female entrepreneurship in development, Minniti and Naudé (2010) remarks that 'evidence to date suggests that a variety of reasons contribute to explaining observed differences in entrepreneurial behaviour across gender and that such differences have significant implications at the macro-economic level'. Some of these differences with a broader societal impact include that women entrepreneurs' businesses tend to be smaller and to provide less employment grow than those owned by men $^{3}$ (Coleman 2007, DuRietz and Henrekson 2000); that women's businesses tend to be less profitable than those of men (Robb and Wolken 2002) and generate lower sales turnover than men, even in same industry comparisons (Chaganti and Parasuraman 1996).

These differences in entrepreneurial propensity and performance between men and women reflect disadvantages and discrimination in education and the labour market. Labour market discrimination against women has been argued to lead to a self-selection of the most highly talented women into labour markets. As a result, less talented women will opt for selfemployment, a characteristic reflected in their enterprises' lower survival and growth rates (see

\footnotetext{
${ }^{3}$ For instance women's firms tend to grow slower in both sales and employment (Nichter and Goldmark, 2009; Amine and Straub, 2009) even if one controls for sectors. Women are also found to have on average lower growth expectations (Justo and DeTienne, 2008).
} 
e.g. Rosti and Chelli, 2005). Furthermore, as a result of perceived underinvestment in their human capital, many women may not have sufficient confidence in their ability to start a firm (Langowitz and Minniti 2007). Yueh (2009) discuss the case of women entrepreneurs in China and supports the idea that lack of self-confidence is a significant constraint hindering women entrepreneurial entry in developing countries.

As a result they also lack access to credit and face higher start-up costs. Horrell and Krishnan (2007), for example, report that female-headed households often lack either assets or incomes, or both, and that this constrains their ability to diversify their economic activities. In this regard a large number of studies have found that access to micro-credit has improved women's decisionmaking autonomy (Amin et al., 1998) and general household welfare and consumption (Kevane and Wydick, 2001).

In conclusion, although much has been learned about the obstacles faced by female entrepreneurs, much less is known about how the level of aggregate activity influences women's decisions about entrepreneurship and even less about how the latter contribute to development (Minniti and Naudé, 2010). The lack of a systematic approach and data has prevented, so far, the formulation of a comprehensive and robust theory of female entrepreneurship and development. As Minniti and Naudé (2010) stress 'no “women only” theory is necessary. However, a solid understanding of how the distinctive characteristics of female entrepreneurship are accounted by existing models of growth would be very desirable for both science and policy'.

\section{Policy Considerations for Enhancing the Developmental Impact of Entrepreneurship}

A proper discussion of the policy implications inherent in the theoretical and empirical overviews in the previous sections would necessitate a separate chapter. The remainder of this chapter can only outline some of the most pertinent issues. Given the "grand ideas" in development economics with which I started this chapter, I will conclude by arguing that the main policy considerations for enhancing the developmental impact of entrepreneurship should be on (i) improving the quality and allocation of entrepreneurial ability and (ii) reducing the need for necessity entrepreneurship - i.e. make entrepreneurship a valued human functioning.

Improving the quality of entrepreneurial ability means not only improving the skills and education of entrepreneurs (their 'human capital') but moreover focusing on the innovative abilities of entrepreneurs. Indeed from the discussion in sections 2 and 3 of this chapter the implication is that it is innovative entrepreneurship that is most desirable for growth. Innovation policy should therefore a vital component of entrepreneurship promotion in developing countries (as it also remains the case in advanced economies).

Stimulation of innovation has not been paramount in most development agencies or donor's private sector development (PSD) programmes, nor in national entrepreneurship support 
programmes. The only innovation relevant aspects of such support programmes have been their concern to improve the general business environment (a prerequisite for innovation) and to argue for patent protection - and to a lesser extent basic research (Lindahl, 2005). As such policies tend to be more concerned with improving static and allocative efficiency and not dynamic efficiency, although the latter is more important from a job creation and growth point of view (Evenett, 2005).

Taking aim at improving dynamic market efficiency through raising innovation, and aiming to limit necessity entrepreneurship, may have implications for policy that runs counter to many current entrepreneurship policies. For instance many aim to improve static and allocation efficiencies in markets through increasing competition (competition policy). However, this misses the fact that with underdeveloped financial markets in developing countries, raising competition might not improve dynamic efficiency, because in the absence of financial markets firms can only finance innovation through profits. If too much competition erodes their profits, it will also erode their innovative activities. And reducing the need for necessity entrepreneurship may imply policies to encourage job-creation and provide social security, policies not popularly associated with an entrepreneurial economy.

Promoting innovative entrepreneurship (and to an extent also labour market and social security policies) in developing countries runs into further difficulties in that there is a broad lack of sufficient impact evaluations ${ }^{4}$ with which to judge what works and what does not (Lerner (2009). Lopez-Acevedo and Tinajero (2010:2) mention that most existing evaluations entrepreneurship policies typically do not consider biases due to unobserved firm heterogeneity or self-selection, tend to be qualitative rather than quantitative, and cannot keep track with continual changes in programmes over time. Many 'impact' studies also do not attempt to attribute impacts or outcomes to interventions (White, 2009). Lack of reliable SME-data makes evaluation and crosscountry comparisons of programmes difficult (Ardic et al., 2011). There is thus a need for much more rigorous empirical evidence as to what works and why, with respect to entrepreneurship policies and general, and even more so with respect to the impact of innovation policies (Braunerhjelm, 2010; McKenzie, 2011).

\section{Concluding Remarks}

This paper has shown is that a reconsideration of entrepreneurship's role in development leads to three novel realizations. One, consideration of entrepreneurship in development provides fresh perspectives on three of the "grand" ideas in development economics; Two, entrepreneurship influences development outcomes positively as well as negatively; and three, entrepreneurship is in turn significantly determined by the dynamics of development.

\footnotetext{
${ }^{4}$ Impact evaluation (or attribution analysis) is 'a with versus without analysis: what happened with the programme (a factual record) compared to what would have happened in the absence of the programme (which requires a counterfactual, either implicit or explicit’ (White, 2011:3).
} 
Entrepreneurship is therefore a valid and important subject of study for development scholars, and development is a worthwhile subject of study for entrepreneurship and management scholars. The growing availability of more and better data from emerging and developing economies, the increasing adoption of rigorous evaluation methods in policy assessments, and likelihood of closer collaboration across disciplines, all bode well for the intersection of development and entrepreneurship.

\section{References}

Ács, Z.J., Desai, S. and Hessels, J. (2008a). 'Entrepreneurship, economic development and institutions’, Small Business Economics, 31: 219-234.

Ács, Z.J., Desai, S. and Klapper, L. (2008b). ‘What Does “Entrepreneurship” data really show?, Small Business Economics Journal, 31 : 265-281.

Ács, Z.J. and Naudé, W.A. (2012).’Entrepreneurship, Stages of Development, and Industrialization' (프 Szirmai, A., Naudé, W.A. and Alcorta, L. eds. Pathways to Industrialization in the $21^{\text {st }}$ Century. Oxford: Oxford University Press. Chapter 14).

Alkire, S. (2002). Valuing Freedoms: Sen’s Capability Approach and Poverty Reduction. Oxford: Oxford University Press.

Andersson, P. (2008). Happiness and Health: Well-Being among the Self-Employed, Journal of Socio-Economics, 37, 213-236.

Audretsch, D.B. (2007). 'Entrepreneurship Capital and Economic Growth', Oxford Review of Economic Policy’, 23: 63-78.

Audretsch, D.B. and Keilbach, M.C. (2004). Entrepreneurship Capital and Economic Performance', Regional Studies, 38 (8): 949-959.

Audretsch, D.B., Grilo, I. And Thurik, R. (2007). Handbook of Research on Entrepreneurship Policy. Cheltenham: Edward Elgar.

Audretsch, D.B., Keilbach, M.C. and Lehmann, E.E. (2006). Entrepreneurship and Economic Growth. Oxford: Oxford University Press.

Baumol, W.J. (1990). 'Entrepreneurship: Productive, Unproductive and Destructive', The Journal of Political Economy 98(5): 893-921.

Benz, M. and Frey, B.S. (2004). Being Independent Raises Happiness at Work, Swedish Economic Policy Review, 11, 95-134.

Benz, M. and Frey, B.S. (2008). Being Independent is a Great Thing: Subjective Evaluations of SelfEmployment and Hierarchy, Economica, 75, 362-383.

Blanchflower, D.G. (2004). 'Self-Employment: More May Not be Better', Swedish Economic Policy Review, 11: 15-73. 
Block, J. and Koellinger, P. (2009). I Cant get No Satisfaction -Necessity Entrepreneurship and Procedural Utility, Kyklos, 62 (2), 191-209

Bruton, G.D., Ahlstrom, D. and Obloj, K. (2008). 'Entrepreneurship in Emerging Economies: Where Are We Today and Where Should the Research Go in the Future', Entrepreneurship Theory and Practice, January : 1-14.

Casson, M., Yeung, B., Basu, A. and Wadeson, N. (2006). The Oxford Handbook of Entrepreneurship. Oxford: Oxford University Press.

Ciccone, A. and Matsuyama, K. (1996). 'Start-up Costs and Pecuniary Externalities as Barriers to Economic Development’, Journal of Development Economics, 4: 33-59.

Clark, D.A. (2005). 'The Capability Approach: Its Development, Critiques and Recent Advances', Global Poverty Research Group Working Paper WPS-032. University of Manchester.

Davidsson, P. (2004). Researching Entrepreneurship. New York: Springer.

De Meza, D. and Webb, D. (1987). 'Too Much Investment: A Problem of Assymetric Information', Quarterly Journal of Economics, 102(2): 281-92.

De Meza, D. and Webb, D. (1999). 'Wealth, Enterprise and Credit Policy', Economic Journal, 109(455): 153-63.

De Paula, A. and Scheinkman, J.A. (2007). 'The Informal Sector', NBER Working Paper 13486, Cambridge MA: National Bureau of Economic Research.

Desai, S. (2011). 'Measuring Entrepreneurship in Developing Countries’ (In Naudé, W.A. ed. Entrepreneurship and Economic Development. Basingstoke: Palgrave Macmillan. Chapter 4).

Evans, D.S., and B. Jovanovic (1989). 'As Estimated Model of Entrepreneurial Choice Under Liquidity Constraints’, Journal of Political Economy 97(4): 808-27.

Ghatak, M., Morelli, M. and Sjöström, T. (2007). 'Entrepreneurial Talent, Occupational Choice and Trickle Up Policies’, Journal of Economic Theory, 137(1): 27-48.

Gollin, D. (2008). 'Nobody's business but my own: Self-employment and small enterprise in economic development’, Journal of Monetary Economics, 55 (2) : 219-233.

Gries, T. and Naudé, W.A.(2010).'Entrepreneurship and Structural Economic Transformation', Small Business Economics Journal, 34 (1): 13-29.

Gries, T. and Naudé, W.A.(2011). 'Entrepreneurship and Human Development: A Capability Approach', Journal of Public Economics, 95 (3): 216-224.

Hamilton, B.A. (2000). 'Does Entrepreneurship Pay? An Empirical Analysis of the Returns to Self-Employment’, Journal of Political Economy, 108(3): 604-31.

Hausmann, R. and Rodrik, D. (2003). 'Economic Development as Self-discovery', Journal of Development Economics, 72(2): 603-33.

Jovanovic, B. (1982). ‘Selection and Evolution of Industry’, Econometrica, 50(3): 649-70. 
Kanbur, S.M. (1979). 'Of Risk-Taking and the Personal Distribution of Income', Journal of Political Economy, 87(4): 769-97.

Kirzner, I.M. (1973). Competition and Entrepreneurship. Chicago: University of Chicago Press.

Leff, N. (1979). 'Entrepreneurship and Economic Development: The Problem Revisited', Journal of Economic Literature, 17: 46-64.

Lewis, W.A. (1954). 'Economic Development with Unlimited Supplies of Labour', The Manchester School, 28(2): 139-191.

Lewis, W.A. (1988). 'The Roots of Development Theory' (In Chenery, H.B. and Srinivasan, T.N. eds. Handbook of Development Economics, volume 1. Elsevier.).

Lucas, R.E. (1978). 'On the Size Distribution of Business Firms', Bell Journal of Economics, 9: 508-23.

Maloney, W.F. (2004). 'Informality Revisited', World Development, 32: 1159-78.

Michelacci, C. (2003). 'Low Returns in R\&D Due to Lack of Entrepreneurial Skills', The Economic Journal 113: 207-25.

Minniti, M. And Nardone, C. (2007). 'Being in Someone Else's Shoes: Gender and Nascent Entrepreneurship’, Small Business Economics, 28 (2-3): 223-239.

Minniti, M. and Naudé, W.A. (2010). 'What do We Know About the Patterns and Determinants of Female Entrepreneurship Across Countries?', The European Journal of Development Research, 22 (3): 277-293.

Murphy, K., Schleifer, A. and Vishny, R. (1991). 'The Allocation of Talent: Implications for Growth', Quarterly Journal of Economics, 106(2): 503-30.

Naudé, W.A. (2008). 'Entrepreneurship in Economic Development', UNU-WIDER Research Paper no. 20/2008, United Nations University, Helsinki.

Naudé, W.A. (2010). 'Entrepreneurship, Developing Countries and Development Economics: New Approaches and Insights', Small Business Economics Journal, 34 (1): 1-12.

Naudé, W.A. (2011a). Entrepreneurship and Economic Development. Basingstoke: Palgrave Macmillan.

Naudé, W.A. (2011b). 'Entrepreneurship is not a Binding Constraint on Growth and Development in the Poorest Countries', World Development, 39 (1), 33-44.

Nelson, R.R. and Pack, H. (1999). 'The Asian Miracle and Modern Growth Theory', The Economic Journal, 109(457): 416-36.

Nussbaum, M.C. (2000). Women and Human Development: The Capabilities Approach. Cambridge: Cambridge University Press.

Peretto, P.F. (1999). 'Industrial Development, Technological Change, and Long-Run Growth', Journal of Development Economics, 59: 389-417. 
Rada, C. (2007). 'Stagnation or Transformation of a Dual Economy through Endogenous Productivity Growth', Cambridge Journal of Economics, 31: 711-40.

Reynolds, P.D., Bosma, N. Autio, E. Hunt, S. DeBono, N. Servais, I. Lopez-Garcia P.and Chin N. (2005). 'Global Entrepreneurship Monitor: Data Collection Design and Implementation 1998-2003’, Small Business Economics, 24: 205-231.

Robeyns, I. (2003). 'The Capability Approach: An Interdisciplinary Introduction. Mimeo: Amsterdam School of Social Sciences, Dec.

Robeyns, I. (2005). 'The Capabilities Approach: A Theoretical Survey', Journal of Human Development, 6 (1): 93-114.

Schumpeter, J.A. (1934). The Theory of Economic Development. Cambridge MA: Harvard University.

Schumpeter, J.A. (1950). Capitalism, Socialism and Democracy. New York: Harper \& Row.

Schumpeter, J.A. (1961). The Theory of Economic Development. New York: Oxford University Press.

Sen, A. (2000). Development as Freedom. New York: Anchor Books.

Shane, S. (1997). 'Who is Publishing the Entrepreneurship Research?', Journal of Management, 23(1): 83-95.

Shane, S. (2000). 'Prior Knowledge and the Discovery of Entrepreneurial Opportunities', Organizational Science, 11 (4): 448-469.

Shane, S. and Venkataraman, S. (2000). 'The Promise of Entrepreneurship as a Field of Research', Academy of Management Review, 25(1): 217-26.

Stam, E. And Wennberg

Van Praag, M. and Versloot, P.H. (2007). 'What is the Value of Entrepreneurship? A Review of Recent Research’, Small Business Economics, 29: 351-382.

Wennekers, S. and Thurik, R. (1999). 'Linking Entrepreneurship and Economic Growth', Small Business Economics, 13(1): 27-55.

Wennekers, S. and Thurik, R. (1999). 'Linking Entrepreneurship and Economic Growth', Small Business Economics, 13 (1): 27-55.

Wennekers, S., Van Stel, A., Thurik, R. and Reynolds, P. (2005). 'Nascent Entrepreneurship and the Level of Economic Development’, Small Business Economics, 24: 293-309.

Wiggens, S.N. (1995). 'Entrepreneurial Enterprises, Endogenous Ownership and Limits to Firm Size’, Economic Inquiry, 33(1): 54-69. 


\section{The UNU-MERIT WORKING Paper Series}

2012-01 Maastricht reflections on innovation by Luc Soete

2012-02 A methodological survey of dynamic microsimulation models by Jinjing Li and Cathal O'Donoghue

2012-03 Evaluating binary alignment methods in microsimulation models by Jinjing Li and Cathal O'Donoghue

2012-04 Estimates of the value of patent rights in China by Can Huang

2012-05 The impact of malnutrition and post traumatic stress disorder on the performance of working memory in children by Elise de Neubourg and Chris de Neubourg

2012-06 Cross-national trends in permanent earnings inequality and earnings instability in Europe 1994-2001 by Denisa Maria Sologon and Cathal O'Donoghue

2012-07 Foreign aid transaction costs by Frieda Vandeninden

2012-08 A simulation of social pensions in Europe by Frieda Vandeninden

2012-09 The informal ICT sector and innovation processes in Senegal by Almamy Konté and Mariama Ndong

2012-10 The monkey on your back?! Hierarchical positions and their influence on participants' behaviour within communities of learning by Martin Rehm, Wim Gijselaers and Mien Segers

2012-11 Do Ak models really lack transitional dynamics? by Yoseph Yilma Getachew

2012-12 The co-evolution of organizational performance and emotional contagion by $\mathrm{R}$. Cowan, N. Jonard, and R.Weehuizen

2012-13 "Surfeiting, the appetite may sicken": Entrepreneurship and the happiness of nations by Wim Naudé, José Ernesto Amorós and Oscar Cristi

2012-14 Social interactions and complex networks by Daniel C. Opolot

2012-15 New firm creation and failure: A matching approach by Thomas Gries, Stefan Jungblut and Wim Naudé

2012-16 Gains from child-centred Early Childhood Education: Evidence from a Dutch pilot programme by Robert Bauchmüller

2012-17 Highly skilled temporary return, technological change and Innovation: The Case of the TRQN Project in Afghanistan by Melissa Siegel and Katie Kuschminder

2012-18 New Technologies in remittances sending: Opportunities for mobile remittances in Africa Melissa Siegel and Sonja Fransen

2012-19 Implementation of cross-country migration surveys in conflict-affected settings: Lessons from the IS Academy survey in Burundi and Ethiopia by Sonja Fransen, Katie Kuschminder and Melissa Siegel

2012-20 International entrepreneurship and technological capabilities in the Middle East and North Africa by Juliane Brach and Wim Naudé

2012-21 Entrepreneurship, stages of development, and industrialization by Zoltan J. Ács and Wim Naudé

2012-22 Innovation strategies and employment in Latin American firms by Gustavo Crespi and Pluvia Zuniga

2012-23An exploration of agricultural grassroots innovation in South Africa and implications for innovation indicator development by Brigid Letty, Zanele Shezi and Maxwell Mudhara

2012-24 Employment effect of innovation: microdata evidence from Bangladesh and Pakistan by Abdul Waheed 
2012-25 Open innovation, contracts, and intellectual property rights: an exploratory empirical study by John Hagedoorn and Ann-Kristin Ridder

2012-26 Remittances provide resilience against disasters in Africa by Wim Naudé and Henri Bezuidenhout

2012-27 Entrepreneurship and economic development: Theory, evidence and policy by Wim Naudé 